\title{
5. The Swedish model of labour market regulation and the EU: is there room for national characteristics in today's constitutional framework?
}

\section{Caroline Johansson}

\section{INTRODUCTION}

The Maastricht Treaty, signed in 1992, was viewed as a victory for the political and legislative side of the social dimension at EU level. ${ }^{1} \mathrm{~A}$ few years later, in 1995, Sweden became a member of the EU. Neither the Swedish legislator nor the social partners considered that EU membership interfered with the Swedish model of labour market regulation (henceforth the Swedish model) at the time of EU accession. ${ }^{2}$ Nor was the subsequent development of the social dimension, with several new directives leading to new Swedish legislation, deemed to affect core issues. ${ }^{3}$ Instead, it was the tension between the economic dimension of the EU and national social models - highlighted in the Laval case a decade later - that triggered sharp criticisms and concern. The Laval judgment, together with the other three cases forming the so-called Laval quartet, ${ }^{4}$ touched upon important issues connected to national welfare models, such as

\footnotetext{
1 Or at least as a prominent step for the legislator at EU level: see, for example, Jeff Kenner, EU Employment Law: From Rome to Amsterdam and Beyond (Hart Publishing 2003).

2 Jonas Malmberg, 'Arbetsrätten efter EU-inträdet' [2011] Svensk Juristtidning $431-2$.

3 Barnard describes it as 'an eclectic body of employment law' and comments on the lack of general regulation: see Catherine Barnard, 'EU "Social" Policy: From Employment Law to Labour Market Reform' in Paul Craig and Gráinne de Búrca (eds), The Evolution of EU Law (OUP 2011) 660-1. Furthermore, the level of protection established in directives was often lower than the existing level in Sweden.

4 Case C-438/05 Viking ECLI:EU:C:2007:772; Case C-341/05 Laval ECLI:EU: C:2007:809; Case C-319/06 Commission v Luxemburg ECLI:EU:C:2008:350; Case C-346/06 Rüffert ECLI:EU:C:2008:189.
} 
the right to strike, collective bargaining, the role of collective agreements in public procurement and compliance measures connected to working conditions. The ruling had an impact in Sweden as well as beyond. After the Laval quartet, politicians, trade unions and scholars called for a more social Europe, with a different balance between 'the market' and 'the social'. 5 As Professor Monti concluded in his report from 2010: 'The Court's cases have exposed the fault lines that run between the single market and the social dimension at national level.' 6

But how should these fault lines be bridged? Can it be done at the supranational level? 'The social' is not a homogenous concept. First, it encompasses different areas of law, among others labour law and social security law - areas in which the EU legislator has no or shared competence and where the CJEU has adopted some of its more controversial judgments. ${ }^{7}$ Second, even if there were consensus on the need for more of 'the social', it is not the same as an agreement on how 'the social' should be organised. Member States' welfare models differ to a large extent. ${ }^{8}$ Increased activity in the EU social sphere

5 See, for example, the contributions with national perspectives in Stein Evju (ed), Cross-border Services, Posting of Workers, and Multilevel Governance (Institutt for privatrett 2013) and in Mark Freedland and Jeremias Prassl (eds), Viking, Laval and Beyond (Hart Publishing 2014). For further reading see Catherine Barnard, Employment Rights, Free Movement under the EC Treaty and the Services Directive (Mitchell Working Paper Series, 5/2008); Christian Joerges, 'A Renaissance of the European Economic Constitution' in Ulla Neergaard, Ruth Nielsen and Lynn M. Roseberry (eds), Integrating Welfare Functions into EU Law (DJØF Publishing 2009); Sacha Garben, 'The Constitutional (Im)balance between "the Market" and "the Social"” (2017) 13 European Constitutional Law Review 23. Barnard comments on the extensive amount of contributions dedicated to Viking and Laval in 'The Calm after the Storm: Time to Reflect on EU (Labour) Law Scholarship Following the Decisions in Viking and Laval' in Alan Bogg, Cathryn Costello and A.C.L Davis (eds), Research Handbook on EU Labour Law (Edward Elgar Publishing 2016).

6 Mario Monti, A New Strategy for the Single Market at the Service of Europe's Economy and Society (2010) 68.

7 Sacha Garben, 'Restating the Problem of Competence Creep' in Sacha Garben and Inge Govaere (eds), The Division of Competences between the EU and the Member States (Hart 2017). Apart from the Laval quartet and the area of labour law, Garben mentions health care and education. For an overview of the CJEU's role in national social security see Jaan Paju, 'The Future of National Systems of Social Security in the EU' in Ulf Bernitz, Moa Mårtensson, Lars Oxelheim and Thomas Persson (eds), Bridging the Prosperity Gap in the EU (Edward Elgar Publishing 2018).

8 Gøsta Esping-Andersen, The Three Worlds of Welfare Capitalism (Princeton University Press 1990). Fritz W. Scharpf later used Esping-Andersen's and Hall and Soskice's categories when discussing how EU integration affects Member States differently, in Fritz W. Scharpf, 'The Asymmetry of European Integration, or Why the EU Cannot Be a "Social Market Economy"' (2010) 8(2) Socio-economic Review 211. 
regarding one specific issue might have a negative impact on more general, national issues. This may lead Member States to choose a strategy that slows down, hinders or alters proposals in the social sphere.

Sweden is a good example of such a Member State and will be used as a case study in this chapter. The Swedish legislator has, ever since the negotiations leading up to EU membership, underlined the importance of the Swedish model. ${ }^{9}$ EU membership was decided by a referendum and it was clear that it could not be won without strong trade union support. ${ }^{10}$ The EU social dimension and the importance of safeguarding the autonomy of the Swedish social partners were equally emphasised during the campaign. It is also a common view that Sweden was promised that its model of labour market regulation would not be affected by EU membership. ${ }^{11}$

Safeguarding the Swedish model continues to be a priority, in parallel with a growing belief that it is under threat from the EU. This affects the Swedish position at the negotiation table independently of political majorities, and also the position of the Swedish trade unions in the European social dialogue and in their policy work directed towards Swedish and EU legislators, as well as in providing information to their members. From a Swedish point of view, there is a double threat from the EU level: first from the economic dimension, mainly in terms of negative integration though the case law of the CJEU; second from the attempts to combat the effects of the economic dimension and economic governance by strengthening the social dimension at EU level. ${ }^{12}$

Furthermore, the case study will focus on the process of adopting the Directive on transparent and predictable working conditions (henceforth the Transparency Directive). ${ }^{13}$ The Transparency Directive is chosen since it aims to regulate issues that draw the boundaries of labour law, such as the concept of worker - issues that, in Sweden, have been left to the social partners. The Directive is potentially a second generation Cinderella directive, ${ }^{14}$ meaning that it might entail more than its wording would seem to suggest. The focus

\footnotetext{
9 Government Bill 1994/95:19, 228-9.

10 Malmberg (n 2) 431-2.

11 The promise was made by Commissioner Padraig Flynn in correspondence with the Swedish Ministry of Employment. The correspondence is found in Government Bill 1994/95:19, annex 12.

12 See Fritz W. Scharpf, 'De-constitutionalisation of European Law' and Garben (n 7) in Garben and Govaere (eds) (n 7).

13 Directive of the European Parliament and of the Council (EU) 2019/1152 of 20 June 2019 on transparent and predictable working conditions in the European Union [2019] OJ C186/105.

14 Jon Clark and Mark Hall, 'The Cinderella Directive: Employee Rights to Information about Conditions Applicable to Their Contract or Employment Relationship' (1992) 21 Industrial Law Journal 106.
} 
of this chapter is not on the tension between 'the economic' and 'the social', but on the tension between 'the social' at EU level and 'the social' at national level. The aim is to illustrate this tension by using the position of the Swedish social partners, the government and the Parliament in the negotiations and the adoption of the Transparency Directive.

After a discussion of the main features characterising the European Social Model after the adoption of the Lisbon Treaty (section 2), the fundamental elements of the Swedish model will be outlined so as to put the Swedish perspective in context (section 3). Following this is an account of the process that led to the adoption of the Transparency Directive (section 4) and of the Swedish response and position (section 5). Section 6 concludes by discussing the relationship between a national social model and the European Social Model in light of the current EU constitutional framework.

\section{THE EUROPEAN SOCIAL MODEL(S) IN THE FRAMEWORK OF THE LISBON TREATY}

The European Social Model is not easy to describe. As Barnard aptly writes: '[t]he phrase "European social model" has been used to mean all things to all institutions. ${ }^{15}$ It can be defined widely, encompassing the multi-level governance of a variety of issues, such as labour law, social security law, housing and education, or more narrowly, with a focus on hard law stemming from the EU institutions. I find the former more useful, which also entails that the use of 'model' in the singular is misleading. It might be fairer to say that there are various European Social Models that have many features in common, because of both a common history and the development of the EU. ${ }^{16}$ From the EU perspective, one way to define 'the Model' is to look at the constitutional structure for social policy, the existing acquis and the political ambitions at EU level - in other words, the social dimension of the EU. The social dimension has developed over time, which has led to a stronger constitutional basis for

15 Catherine Barnard, 'EU Employment Law and the European Social Model: The Past, the Present and the Future' (2014) 67(1) Current Legal Problems 199.

16 Brian Bercusson points out the importance of the relationship between EU labour law and national labour law systems in European Labour Law (CUP 2009). This way of understanding EU labour law is used by several scholars: see, for example, Bogg, Costello and Davis (n 5) and Andrea Iossa, Collective Autonomy in the European Union: Theoretical, Comparative and Cross-border Perspectives on the Legal Regulation of Collective Bargaining (Mediatryck 2017). 
social rights, a larger acquis stemming from the EU level and a broader policy area for the EU institutions. ${ }^{17}$

In this section, I will focus on the scholarly discussion of the European Social Model(s) as enshrined in the framework of the Lisbon Treaty. A premise of the discussion is that, after the Laval quartet, it became clear that the economic dimension takes precedence over the social. A question often posed in that regard is whether the balance can be altered within the existing constitutional framework. The discourse can be divided into those who argue that a balance can be struck within the Lisbon framework, those who call for a stronger EU legislator and those who claim that the EU competence is too broad..$^{18}$

The argument that the current constitutional framework can enable a stronger social dimension is supported by an increasing number of scholars. ${ }^{19}$ Almost a decade ago, Schiek argued that the EU project has always experienced dynamic development and the Lisbon Treaty provides a basis for a more socially oriented approach. ${ }^{20}$ Over time, social values have gained a more prominent position and now weigh more heavily in relation to the 'four freedoms' than they did before. As time goes on, the balance between the 'social' and the 'economic' could continue shifting. Advocates of a stronger social dimension could make this happen using the possibilities found in the Lisbon

17 The development of EU labour law over time is presented in Kenner (n 1). Other contributions adapt a similar historical approach at least to some extent, see, for example, Catherine Barnard, EU Employment Law (OUP 2012).

18 I elaborate this mainly in my thesis with inspiration from Miguel P. Maduro's models. See Miguel P. Maduro, We, the Court: The European Court of Justice and the European Economic Constitution (Hart Publishing 1998) and Caroline Johansson, Tjänstepensionen möter EU-rätten (Iustus 2018) ch 9. For another way of conceptualising these issues see Dagmar Schiek, 'Towards More Resilience for a Social EU: The Constitutionally Conditioned Internal Market' (2017) 13 European Constitutional Law Review 611, where she argues for an analysis in three dimensions. First, market constitutionalisation can be presented as conflicts between national and EU competences. Second, adjudication of (social) policy is perceived as a potentially illegitimate limitation of the democratic legislative process. Third, the potential tension in substance between the single market and social policy. For further reading see Roger Blanpain, 'The Treaty Needs to Be Amended' (2013) 4(1) European Labour Law Journal 28; Scharpf (n 8); Christian Joerges and Florian Rödl, 'Social Market Economy as Europe's Social Model?' (2004) EUI Working Papers, Law 2004/8.

19 Dagmar Schiek, Economic and Social Integration (Edward Elgar Publishing 2012); Barnard (n 17); Phil Syrpis and Tonia Novitz, 'The EU Internal Market and Domestic Labour Law: Looking beyond Autonomy' in Alan Bogg, Cathryn Costello, A.C.L. Davies and Jeremias Prassl (eds), The Autonomy of Labour Law (Hart Publishing 2015), Alexandris Polomarkakis, 'From Economic to Symbiotic Constitutionalism: A Belated Post-Lisbon, Post-Crisis Transformation?' (2019) 25 European Public Law 421. I should add that not all of them present the argument with clear conviction.

20 Schiek (n 19). For more recent developments see Schiek (n 18). 
Treaty, resulting in an evolution towards a union governed by new pluralistic methods. ${ }^{21}$ The 'tool box' that the Lisbon Treaty provides also makes it possible to argue that national characteristics shall be taken into account. Article 4(2) TEU establishes that the EU shall respect the Member States' national identity. Whether respecting Member States' national identity should be viewed as an obligation for the EU or as one interest among others for the CJEU to consider in its proportionality test is not yet clear. ${ }^{22}$ However, this could push the Court to revise its case law in a more social and pluralistic direction.

The Lisbon Treaty contains further features that may lead to a stronger social dimension. First, it introduced in the Treaty on European Union an acknowledgement that the EU 'shall work for' a competitive social market economy (Article 3(3) TEU); second, it established a stronger recognition of social rights through, inter alia, the conferral of a binding legal status on the EU Charter (Article 6 TEU); and third, an increased use of soft law measures to coordinate labour law and social security law (Article 2(3) TFEU). ${ }^{23}$ Nonetheless, the CJEU has not changed how it strikes the balance between the 'four freedoms' and collective labour rights. ${ }^{24}$ Furthermore, many of the soft law measures used to coordinate labour law and social security law have not been used to promote enhanced social protection. This is particularly evident in relation to the measures taken in connection to the euro crisis, and that now have been institutionalised in the European Semester. ${ }^{25}$ Despite these discour-

${ }^{21}$ See, for example, the discussion in Olivier de Shutter and Jacques Lenoble, Reflexive Governance: Redefining the Public Interest in a Pluralistic World (Hart Publishing 2010).

22 Armin von Bogdandy and Stephan Schill, 'Overcoming Absolute Primacy: Respect for National Identity Under the Lisbon Treaty' (2011) 48(5) Common Market Law Review 1417; Christiaan Timmermans, 'The Competence Divide in the Lisbon Treaty' in Garben and Govaere (n 7).

${ }^{23}$ Christian Joerges in Neergaard, Nielsen and Roseberry (n 5) 40-1. See also Neergard, 'Services of General (Economic) Interest: What Aims and Values Count?' in the same edited volume.

24 Judgment 15 July 2010 Commission v Germany, C-271/08, EU:C:2010:426; Judgment 18 July 2013 Alemo-Herron, C-426/11, EU:C:2013:521; Judgment 15 January 2014 AMS, C-176/12, EU:C:2014:2; Judgment 4 December 2014 FNV Kunsten, C-413/13, EU:C:2014:2411; Judgment 21 December 2016 AGET Ikralis, C-201/15, EU:C:2016:972; and Judgment 24 October 2019 EPSU, T-310/18, EU:T: 2019:757.

25 This area has been much debated: see, for example, Alicia Hinarejos, The Euro Area Crisis in Constitutional Perspective (Oxford University Press 2015); Ana Bobic, 'Accountability through Self-Governance in EU Economic Governance' in Sacha Garben, Inge Govaere and Paul Nemitz (eds), Critical Reflections on Constitutional Democracy in the European Union (Hart Publishing 2019); also Pieter Pecinovsky, ch 4 in this volume. 
aging facts, recent developments seem to be swinging towards a stronger social dimension in the EU, in line with the above-mentioned argument. The political aspirations expressed in the European Pillar of Social Rights ${ }^{26}$ (henceforth the Social Pillar) paint a more hopeful picture of what the future EU might be like. After the economic crisis and the pressure put on several EU Member States, the Social Pillar is intended to be a tool to overcome the consequences of that crisis. ${ }^{27}$ The way forward is, according to the Commission, to embrace the aim that the EU should be a social market economy. ${ }^{28}$

Is the Social Pillar an early but important step in a process of development that will strengthen the EU social dimension and reconcile the faultlines that Monti identified in his report? Some believe that this might be the case. ${ }^{29}$ On the other hand, there are still those that favour strengthening the legislator at national and/or EU level. ${ }^{30}$ As this chapter will show, today's constitutional framework still raises issues in connection to minority voices and national characteristics.

\section{THE SWEDISH MODEL: A SKETCH OF ITS FUNDAMENTAL FEATURES}

It is often stated that the Swedish social partners have broad autonomy and that the Swedish state does not intervene in labour market issues. ${ }^{31}$ To a large extent, that is true. However, the Swedish state has taken an active role in promoting and safeguarding collective bargaining. Hence, a prominent feature of the Swedish model is that it primarily protects collective bargaining rather than substantive individual rights, in the belief that bargaining will deliver employment protection.

First, for a long time the state refrained from legislating on employment protection. The first labour law legislation concerned the legal status of col-

\footnotetext{
26 Interinstitutional Proclamation on the European Pillar of Social Rights (2017/C 428/09)

27 European Commission, Launching a consultation on a European Pillar of Social Rights $\operatorname{COM}(2016) 127$ final, 3-4.

28 ibid, 2-3.

29 Silvana Sciarra, Solidarity and Conflict: European Social Law in Crisis (CUP 2018); Polomarkakis (n 19) 421-44.

30 Scharpf (n 12), Fritz Scharpf, 'After the Crash: A Perspective on Multilevel European Democracy’ (2015) 21(3) European Law Journal 384.

31 See, for example, Reinhold Fahlbeck, 'Industrial Relations and Collective Labour Law: Characteristics. Principles and Basic Features' (2002) 43 Scandinavian Studies in Law 87.
} 
lective agreements, negotiation procedures and dispute-solving measures. ${ }^{32}$ Afterwards followed decades of autonomous collective bargaining and little state intervention, albeit under the threat of legislation in some instances. ${ }^{33}$ This order was kept until the 1970s, when the Employment Protection Act, the Co-Determination Act and an Act on Trade Union Representatives' Rights were adopted. ${ }^{34}$ Hence, during the 1970 s, not only employment protection but also the legislation regarding negotiations and trade union activities were strengthened.

Second, the existing legislation regarding negotiation procedures, employment protection and working time is to a large extent semi-discretionary, meaning that the social partners can choose to deviate from part of the legislation by concluding collective agreements. ${ }^{35}$ Semi-discretionary legislation can be replaced by a clause in a collective agreement irrespective of whether the clause is more or less favourable for the individual worker. This is not seen as a problem because the collective agreement is supposed to be viewed as a whole, and weaker protection in one respect can be counterbalanced with stronger protection or more favourable benefits in other aspects of working life. $^{36}$

Third, the industrial relations approach is strong in Sweden regarding enforcement of collective agreements, employment protection legislation and work environment issues. ${ }^{37}$ Trade union representatives hold a special position in the workplace. Disputes are preceded by mandatory negotiations between the social partners, primarily at local level, before they reach the Labour Court. Regarding the work environment, there are public inspectorates but there are also workplace representatives that have a mandate to react to health and safety issues, for example to demand that work be temporarily stopped if a danger emerges. ${ }^{38}$ There is no public enforcement of employment protection.

32 The Collective Agreements Act, see Government Bill 1928: 39; Folke Schmidt, The Law of Labour Relations in Sweden (Harvard University Press 1962).

33 The main example is the Basic Agreement (Huvudavtalet) concluded at inter-sectoral level in 1938, which, amongst other things contained rules regarding industrial peace and mediation, see Schmidt (n 32) 31.

${ }_{34}$ Lag (1974:12) om anställningsskydd; lag (1976:580) om medbestämmande $i$ arbetslivet; lag (1974:358) om facklig förtroendemans ställning på arbetsplatsen.

35 This is not without exceptions. Work environment, non-discrimination and the requirement that dismissals have just cause are not semi-discretionary.

36 The social partners are, however, not allowed to inappropriately undermine employment protection. The Labour Court has given the social partners broad discretion: see Labour Court judgment 1995 no 108 and Labour Court judgment 2006 no 82.

37 Jonas Malmberg (ed), Effective Enforcement of EC Labour Law (Iustus 2003).

38 Miriam Kullman, Enforcement of Labour Law in Cross-Border Situations (Wolters Kluwer 2015) 272. 
The trade unions have in practice taken the main responsibility to ensure that employers comply with collective agreements and legislation.

In sum, the Swedish model is characterised by strong autonomous features, but these features have not developed in a vacuum. Instead, the Swedish legislator has had an important role in ensuring the framework for collective bargaining, trade union representatives and the right to take collective action. In Iossa's words, 'industrial relations are private relations, whose autonomous functioning has been recognised and promoted by the legal system' ${ }^{39}$ Within the Swedish legal system, the social partners hold a strong position in the labour market, ranging from identifying the need for regulation through collective agreements to enforcing collective agreements and, finally, solving disputes through negotiation and sometimes arbitration. When a dispute goes to court, the social partners are represented in the Labour Court. To conclude, the established social partners have strong agency and a common interest in safeguarding that agency.

\section{THE PROCESS THAT LED TO THE ADOPTION OF THE TRANSPARENCY DIRECTIVE}

\subsection{The Social Pillar as Ground}

As already mentioned, the European Social Pillar can be viewed as a step forward towards a stronger European social dimension. Contrary to the initial Proposal, the Social Pillar concerns all EU citizens and all third-country nationals with legal residence. ${ }^{40}$ It is also supposed to cover all persons in employment, independent of duration and modality (Article 12). According to the Preamble and the preparatory documents, the Social Pillar is needed to confront the impact of economic crisis and changes in the labour market. ${ }^{41}$ This is also evident from the 20 principles of the Social Pillar.

The Social Pillar is not a legal act. Instead, the Preamble indicates that its aim is to serve as a guide to efficient employment and social outcomes when responding to current and future challenges (para 12). The rights and principles of the Social Pillar need to be incorporated in legislative acts in order to

\footnotetext{
39 Iossa (n 16) 162.

40 Compare para 15 in the Preamble with Commission, 'Establishing a European Pillar of Social Rights' $\operatorname{COM(2017)} 250$ final, 5, where it is stated that the main target was the euro countries.

${ }^{41}$ European Commission (n 27) 3; European Commission, A European agenda for the collaborative economy $\operatorname{COM}(2016) 356$ final. See also Nicola Countouris and Valerio De Stefano, New Trade Union Strategies for New Forms of Employment (ETUC 2019).
} 
be enforceable. Furthermore, it does not provide the EU with new legislative competences. Article 6 on the right to fair wages is an example of an issue outside the competence of the EU. ${ }^{42}$ At EU level, the Social Pillar has given an incentive to revise directives in the social policy field..$^{43}$ It may also facilitate more ambitious social initiatives when directives are revised - a good example of this is the process for the revision of the Written Statement Directive from $1991(91 / 533 / \mathrm{EEC})$.

\subsection{Proposal}

The first Proposal of the Transparency Directive saw the light at the end of 2017 and was far more extensive than the Written Statement Directive from 1991, which only dealt with information that the employer was required to provide to employees regarding their working conditions. The 2017 Proposal, on the other hand, comprised both an extended list of information that the employer was required to give the employee and substantive rules, mainly focused on atypical forms of work.

The Proposal and the Directive that was later adopted are based on Article 153 TFEU, and the Preamble refers to both Article 31 of the EU Charter regarding fair and just working conditions and the principles found in Articles 5 and 7 in the Social Pillar. The principles of the Social Pillar appear to have affected the content of the 2017 Proposal. The general objective in Article 1 of the Proposal was to promote more secure and predictable employment, while ensuring labour market adaptability and improving living and working conditions. The specific objectives through which the general aim would be addressed, according to the explanatory memorandum, were defined as follows: first, to improve workers' access to information concerning their working conditions; second, to improve working conditions for all workers, notably those in new and non-standard employment, while preserving scope for adaptability and for labour market innovation; third, to improve compliance with working conditions standards through enhanced enforcement; and fourth, to improve transparency in the labour market. ${ }^{44}$ The second and the third objectives are mainly novelties.

42 It has not hindered the Commission from proposing a directive on minimum wages: see Commission, 'Proposal for a Directive of the European Parliament and the Council on adequate minimum wages in the European Union' COM(2020) 682 final.

$43 \operatorname{COM}(2017) 250,8$.

44 European Commission, Proposal for a Directive of the European Parliament and of the Council on transparent and predictable working conditions in the European Union, COM(2017) 797 final, 3. 
The extended revision was justified both in the REFIT evaluation and by the Social Pillar. In the REFIT evaluation, changes in the labour market were identified as an important reason for the need to evaluate the Directive. ${ }^{45}$ This was also acknowledged by the European Parliament in connection to the consultation on the European Pillar of Social Rights. ${ }^{46}$ Later the same year, it urged the Commission to consider new forms of employment when evaluating the Written Statement Directive. ${ }^{47}$ The Commission's response was to include a definition of 'worker' in the 2017 Proposal based on the CJEU case law. The aim was to hinder Member States excluding workers with short or temporary employment contracts. ${ }^{48}$ As will be discussed later, the final version of the Transparency Directive does not contain such a definition.

Garben and Kilpatrick pointed out that the diversity of work performers, the gaps in employment protection and the uncertainty regarding which workers are covered by labour law regulations are key priorities in order to complete a floor of social rights. ${ }^{49}$ From that perspective, the 2017 Proposal must have been seen as a step towards ensuring atypical workers' rights in particular. The Swedish government's position was, on the other hand, hesitant; the Swedish social partners were rather reluctant, and made clear that they did not consider the Proposal to be a viable way forward in light of the features of the Swedish model. ${ }^{50}$

\subsection{The Swedish Response to the Proposal}

The Swedish social partners were in agreement that they did not welcome legislative initiatives at EU level regarding the definition of workers. Both the employers' association and the trade union confederations considered the Proposal to be a threat to their autonomy and their ability to regulate working conditions in collective agreements. They feared that it was the first step towards a scenario in which the EU would take over Member States'

45 Commission, REFIT Evaluation of the 'Written Statement Directive (Directive 91/533/EEC), SWD(2017) 205 final, 6.

46 European Parliament resolution of 19 January 2017 on a European Pillar of Social Rights.

47 European Parliament resolution of 4 July 2017 on working conditions and precarious employment, para 27.

$48 \operatorname{COM}(2017) 797,2-3$.

49 Sacha Garben and Claire Kilpatrick, 'Towards a European Pillar of Social Rights: Upgrading the EU Social Acquis' (2017) College of Europe Policy Brief.

50 This is clear from articles in the Swedish press but also from letters sent to the Swedish government and EU institutions. The letters will be referred to below, but four of them are, unfortunately, not available online. 
competences to regulate core issues on national labour markets. ${ }^{51}$ They agreed that the concept of 'worker' should be defined at national level. According to Karla Wixe, manager of the Brussels Office of the Swedish Trade Unions, ${ }^{52}$ the flexible Swedish concept allows the Labour Court to take into account a number of variables when assessing whether a person is considered a worker. Consequently, the mandatory Swedish concept can be adjusted to match changes in the labour market. ${ }^{53}$

A month after the 2017 Proposal was issued, the Swedish government published a preliminary position. While agreeing on the importance of applying fair working conditions to all workers and on the need to revise the Written Statement Directive, it stated that substantive rules at EU level regarding general working conditions and dispute resolution could be considered as a deviation from the Swedish model. The same goes for EU definitions of 'worker' and 'employer'. The Swedish legislator's initial position was therefore that further investigations and clarifications were needed, and that the Swedish model should be safeguarded. ${ }^{54}$

During the first months of 2018 there was intense activity. The social partners jointly worked to influence both the Swedish Parliament and the government regarding the possible invasive effects of the Proposal on the Swedish model. In their communications they put forward four main points that they wanted the Swedish government to focus on. First, the concepts of 'worker' and 'employer' should continue to be defined at national level. Second, collective agreements must not be subject to requirements of clarity, transparency and comprehensiveness, nor to assessments by public authorities. This has clear connections to the CJEU's ruling in the Laval case. Third, the decision as to what constitutes mandatory legislation in the employment relationship must remain a national matter in order to safeguard the Swedish tradition of autonomous regulation. Fourth, the possibility to derogate by means of

${ }^{51}$ Kerstin Ahlberg, 'Parterna i Sverige varnar mot EU-direktiv om anställningsvillkor' (Arbeidsliv $i$ Norden, 1 March 2018).

52 The Brussels Office of the Swedish Trade Unions (Fackliga Brysselkontoret) is the office of the three large trade union confederations in Sweden, whose purpose is to monitor developments in EU politics and legislation and to provide in-depth information on current activities.

53 Simon Markusson, 'Svenska parter välkomnar förhandlingsbart EU-direktiv' (Arbetsvärlden, 7 February 2019). It should, however, be noted that it is probably not only the function of the Swedish concept of 'worker' that is of importance for the Swedish social partners. The final assessment of disputes is made by the Labour Court, where a majority of the judges are representatives of trade unions and employers' associations. If the definition of 'worker' is decided at EU level, the Swedish social partners would lose influence.

54 2017/18:FPM49, p.5. 
a collective agreement must be absolute, and legal matters are to be resolved within the national legal system. ${ }^{55}$ The last point is connected to the tradition of semi-discretional legislation and to the concerns about scrutiny by the CJEU.

In the end, the Swedish Parliament decided to submit to the Commission a reasoned opinion in accordance with Article 6, Protocol no 2 on the application of the principles of subsidiarity and proportionality. ${ }^{56}$ Besides the communication with the social partners, the reasoned opinion was preceded by a discussion in the Parliament's Labour Market Committee. Both the Committee's Proposal and the final reasoned opinion issued by the Parliament concluded that, despite the good reasons to revise the Written Statement Directive to adjust it to today's labour market, the Commission's Proposal would go beyond a mere revision insofar as it prescribes new substantial rights and establishes concepts such as those of both 'employee' and 'employer'. It observed that many of the issues regulated in the Proposal are within the competence of social partners in the Swedish model, so that its adoption could lead to 'disruptions in the well-functioning Swedish system'. ${ }^{57}$

\section{THE FINAL TEXT OF THE TRANSPARENCY DIRECTIVE}

The Transparency Directive was adopted in June 2019. The final version has been revised in various ways, but it still comprises obligations to inform, substantive rules focused on atypical work and procedural rules. The Directive in its entirety will not be analysed here. In line with the social partners' four main points mentioned above, the concept of worker and the social partners' position in the labour market will be scrutinised here.

55 Joint letter (180409). The letter is signed by representatives of the three trade union confederations and of four employers' associations, including representatives from the state sector, regions and municipalities.

56 2017/18:AU11, the Committee on the Labour Market's opinion, 7-10; 2019/20:KU5 The Committee on the Constitution's consideration. For further reading see Bartlomiej Bednarowicz, 'Delivering on the European Pillar of Social Rights: The New Directive on Transparent and Predictable Working Conditions in the European Union' (2019) 48(4) Industrial Law Journal 604.

57 2017/18:AU11, the Labour Market Committee's opinion, with the Parliament's motivated opinion annexed, p.12. 


\subsection{The Concept of Worker}

In the Proposal, the concept of worker was defined in Article 2 as 'a natural person who for a certain period of time performs services for and under the direction of another person in return for remuneration'.

In the final wording of the Directive the concept 'worker' is removed from Article 2. However, in the context of the purpose, subject matter and scope of the Directive, Article 1(2) was rephrased. In the Proposal it was stated only that the Directive lays down minimum rights that apply to every worker in the European Union, whereas the Directive reads as follows: 'This Directive lays down minimum rights that apply to every worker in the Union who has an employment contract or employment relationship as defined by the law, collective agreements or practice in force in each Member State with consideration to the case-law of the Court of Justice.'

Hence, even if there is no definition of who is to be considered a worker according to the Directive, the scope is still connected to the concept as elaborated by the CJEU. The CJEU has established criteria for determining the status of 'worker' in several cases ${ }^{58}$ Recital 8 of the Preamble of the Transparency Directive recalls that the CJEU's interpretation of those criteria should be taken into account in the implementation of the Directive. Domestic workers, on-demand workers, intermittent workers, voucher-based workers, platform workers, trainees and apprentices would then fall within the scope of the Directive if they meet those criteria. Both the Preamble and Article 1(2) suggest that national legislation implementing the Directive shall take into account the EU concept of 'worker' as interpreted by the CJEU. Therefore, it is also very likely that, within the Directive's scope, the concept of 'worker' will evolve concurrently with CJEU case law. The reference to both national law and EU law complicates the interpretation of the scope of the Directive. If the concept of 'worker' within the framework of the Directive includes both the EU concept and national concepts, its scope would be fairly wide especially from a Swedish point of view. Similar to the EU concept of worker, the Swedish concept tends to comprise performers of work who might not be

58 The case law has been elaborated mainly in connection with EU internal market law. Regarding competition law the main cases are Case C-67/96 Albany ECLI:EU: C:1999:430; Case C-180/98 Pavel Pavlov ECLI:EU:C:2000:428; and FNV Kunsten (n 24). Regarding free movement, see, among others: Case 66/85 Lawrie-Blum ECLI: EU:C:1986:284; Case C-85/96 Martinez Sala ECLI:EU:C:1998:217; Case C-337/97 Meeusen ECLI:EU:C:1999:284;14; Case C-270/13 Haralambidis ECLI:EU:C:2014: 1358. Regarding discrimination law, see Case C-256/01 Allonby ECLI:EU:C:2004:18. 
covered by employment protection in other countries. ${ }^{59}$ However, while the EU concept aims at ensuring that the Member States do not circumvent EU law, the Swedish concept aims at ensuring that employment protection as well as collective agreements are not circumvented. Accordingly, the interpretation given by the Labour Court on the concept of 'worker' aims at safeguarding the social partners' collective agreements - something that has not been visible in the CJEU's case law. ${ }^{60}$

Recital 8 of the Preamble excludes genuinely self-employed persons from the scope of the Directive. However, it states that the 'abuse of the status of self-employed person' is often associated with undeclared work and therefore bogus self-employment shall fall within the scope of the Directive. The CJEU has dealt with bogus self-employment in the FNV Kunsten case, in which it stresses the importance of actual independence. ${ }^{61}$ A self-employed person is not subordinated to or integrated in the principal's business, but determines independently his or her own conduct on the market and bears financial or commercial risk. If the independence is merely notional, the person in question should instead be regarded as an employee. As already mentioned, the Swedish concept of worker has broad scope. In addition, an extended concept of worker applies to the right to form trade unions, to take collective action and to conclude collective agreements. The scope of the extended Swedish concept of worker may be wider than the EU concept, since it includes work performers that bear financial risk and can decide what assignments to take. Freelancers and many types of self-employment are therefore covered. ${ }^{62}$ Swedish collective agreements, if not explicitly stated otherwise, usually cover workers in accordance with the traditional, narrower definition. It is, however, within the social partners' discretion to decide that. Hence it is possible, in principle, for

59 Caroline Johansson, 'Occupational Pensions and Unemployment Benefits in Sweden' (2020) 36(3) International Journal of Comparative Labour Law and Industrial Relations 339; Countouris and De Stefano (n 41). In the report, eight European countries are presented, including Sweden.

60 See, for example, Labour Court judgment 2013 no 32, in which the Court scrutinised a business solution consisting of two companies owned by the same persons where one company assigned personnel to the other, and concluded that it was structured in order to circumvent employment protection and the collective agreement that was applicable to the second company. This case has also been discussed in an international context: see Petra Herzfeld Olsson and Erik Sjödin, 'The Fissured Workplace: Some Responses to Contemporary Challenges in Sweden' (2015) 37 Comparative Labor Law \& Policy Journal 143, 150-2.

${ }^{61}$ FNV Kunsten (n 24).

62 Compare with Order of 22 April 2020, B v Yodel, C-692/19, ECLI:EU:C:2020: 288. The case is commented on by Niklas Selberg, 'EU-domstolen: Cykelbud var inte arbetstagare' (2020) 2 EU \& arbetsrätt http://arbetsratt.juridicum.su.se/euarb/20-02/11 .asp, accessed 20 June 2021. 
Swedish trade unions to push for collective agreements to cover those workers who are included in the extended concept of 'worker'. If the scope of the concept is defined at EU level it will ultimately be up to the CJEU to decide, and no longer a question solely for the Swedish social partners.

\subsection{The Social Partners' Position on the Labour Market}

The Swedish social partners' remaining three points concern their autonomy and are connected to the possibility of implementing the Transparency Directive through collective agreements. According to the Transparency Directive, the Member States have the possibility to allow the social partners to conclude collective agreements relating to working conditions regulated in Chapter 3 that differ from the Directive, as long as the agreement respects the overall protection of workers (Article 14). The Article is not an innovation connected to the Transparency Directive. The Temporary Agency Work Directive, for instance, contains a similar provision in connection to the principle of equal treatment (Article 5(3)). ${ }^{63}$

In the official report regarding implementation of the Transparency Directive, the Swedish government proposes, on the basis of Article 14 of the Directive, that social partners shall have the possibility to deviate from national legislation implementing the Directive through a sectoral collective agreement or a collective agreement approved by the social partners at sectoral level ${ }^{64}$ Hence, the new legislation would be semi-discretionary. An important issue to clarify is how to interpret the meaning of the provision 'respecting the overall protection of workers'.

In this regard, the government's report refers to Article 5.3 of the Temporary Agency Work Directive and to the preparatory works connected to its implementation. However, neither the Transparency Directive nor the Temporary Agency Work Directive contain any explanation of what the demand for 'overall protection of workers' means; nor has this been clarified by the CJEU. On the one hand, it could be interpreted to mean that the collective agreement has to contain a clause regulating the same issue and provide protection at least as strong as a certain article in the Directive. On the other hand, it could also be interpreted to mean that the collective agreement as a whole has to provide overall protection that is sufficient, even though a certain issue regulated in the Directive is missing or is provided weaker protection. The latter view is consistent with the above-mentioned view that the collective agreement

63 Directive of the European Parliament and of the Council (EC) 2008/104 of 19 November 2008 on temporary agency work [2008] OJ L327/9.

64 Ministry Publication Series, Ds 2020:14, section 14. 
has to be assessed as a whole. Swedish collective agreements may deviate from semi-discretionary legislation and provide less protection for individual employees regarding certain issues in order to be able to offer stronger protection in other areas, higher wages or occupational benefits. How the balance is struck is within the social partners' discretion.

The report mentions that different views were expressed during the negotiations in the Council on how to interpret the formula 'respecting the overall protection of workers'. ${ }^{65}$ From a Swedish perspective, the social partners have stressed that it is important that the interpretation is consistent with the Swedish model. ${ }^{66}$ Swedish trade union representatives have commented that their view is not shared by trade union colleagues on the European continent, especially not in the south. ${ }^{67}$ The Swedish positions during the negotiations on the Transparency Directive and the Temporary Agency Work Directive are similar. Article 5(3) of the Temporary Agency Work Directive is also a result of the Swedish - or, rather, Nordic - position during the lengthy negotiations in the Council. From the Swedish perspective, it was important that the autonomy of the social partners was ensured. ${ }^{68}$ It was argued that both sides needed some room for trade-offs during negotiations, in line with the tradition of regulating employment through collective bargaining. However, this constitutes a risk for countries in which trade unions' or worker representatives' bargaining power is weak. ${ }^{69}$

According to the government's report, there is a difference between Article 14 and Article 5(3) of the Temporary Agency Work Directive, which might indicate that 'overall protection' should be interpreted differently. The former entails rights in specific situations, while the latter promotes equal treatment in a more general way. However, the statement in the report is that, because there are no further guidelines from the EU, the 'overall protection' in relation to the Transparency Directive will be deemed fulfilled if there is a collective agreement offering overall protection irrespective of whether it contains a clause

65 Ministry Publication Series, Ds 2020:14, 220.

66 This is evident from the joint letters sent to the Swedish Ministry of Employment (180605) and to the European Parliament (190115).

67 Interview with Claes-Mikael Ståhl, representative of the Swedish Trade Union Confederation (LO) in the EU Council of the Labour Market (Arbetsmarknadens EU-råd) (Stockholm, Sweden, 13 August 2020).

${ }_{68}$ Kerstin Ahlberg, 'A Story of a Failure - But Also of Success: The Social Dialogue on Temporary Agency Work and the Subsequent Negotiations between the Member States on the Draft Directive' in Kerstin Ahlberg et al (eds), Transnational Labour Regulation: A Case Study of Temporary Agency Work (SALTSA 2008).

69 Isabelle Schömann and Carolie Guedes, 'Temporary Agency Work in the European Union Implementation of Directive 2008/104/EC in the Member States' (2012) ETUI report 125, 16. 
regulating a certain issue established in the Directive or not. The report concludes by referring to the CJEU for eventual assessment of the compliance of this conclusion with the obligations set by the Directive. ${ }^{70}$ The Swedish social partner would probably prefer to avoid such scrutiny.

\section{IS THERE ROOM FOR NATIONAL CHARACTERISTICS IN TODAY'S CONSTITUTIONAL FRAMEWORK?}

Although Sweden has generally been in favour of strong social policy and typically is categorised as a coordinated or social democratic welfare model, ${ }^{71}$ there is a general hesitance towards many social policy initiatives at EU level. This can to a large extent be explained by the functioning and features of the Swedish model and the role of the social partners. This is also true regarding the Transparency Directive. In the negotiations, the social partners' autonomy was used as an argument by the social partners themselves, by the Swedish government and by the Swedish Parliament. In 2018 the social partners went a step further and created the EU Council of the Labour Market (Arbetsmarknadens $E U-r a ̊ d)$ in order to jointly influence both the Swedish position in negotiations at EU level and the EU institutions. ${ }^{72}$ The Transparency Directive was viewed as an issue of principle and as a starting point for more EU regulation regarding central employment and working conditions. The Swedish social partners have continued their mobilisation against a minimum wage regulation at EU level. ${ }^{73}$

The reason for the social partners' common position against EU initiatives in the social sphere can be boiled down to three points: the risk of losing power or agency; a lack of trust in EU institutions - mainly the CJEU; and the fact that the Swedish model deviates from the majority of the models of labour market regulation in Europe.

First, there seems to be a consensus between government, legislator, trade unions and employers' associations that the Swedish model functions well

\footnotetext{
70 Ministry Publication Series, Ds 2002:14, 219-21.

71 Peter A. Hall and David Soskice (eds), Varieties of Capitalism: The Institutional Foundations of Comparative Advantage (OUP 2001); Esping-Andersen (n 8).

72 Press release, 1 October 2018, Confederation of Swedish Enterprise (Svenskt Näringsliv) website (www.svensktnaringsliv.se/material/pressmeddelanden/parterna -bildar-rad-for-samverkan-i-eu-fragor_720356.html accessed 17 June 2021) and a joint statement published in Arbetet, 10 December 2018 (https://arbetet.se/2018/12/10/ arbetsmarknadens-eu-rad-varnar-svenska-modellen-i-eu/ accessed 17 June 2021).

73 Interview with Claes-Mikael Ståhl (n 67). The Swedish social partners share their concern with their Danish colleagues: Kerstin Ahlberg, 'Svenska parter enade mot lag om europeisk minimilön' (2019) 3-4 EU \& Arbetsrätt; Anna Wetter Ryde, Europeisk minimilön: Rättsligt grund och politiskt tryck (SIEPS 2020).
} 
and should be preserved. The established trade unions and employers' associations have in common that they prefer to have control over labour market issues. However, EU legislation in the field of labour law is not new. Yet, the more detailed EU legislation gets and the more it addresses core issues for the national dimension, the less room for manoeuvre the Swedish social partners are likely to be left with.

Second, when becoming a member of the EU, Sweden was guaranteed that its model of labour market regulation would not be affected. Both the state and the social partners were convinced of that until the Laval judgment. The judgment cut through core issues, such as wage bargaining and the right to take collective action, in which the discretion of the social partners is broad. ${ }^{74}$ Collective action is not an ultima ratio measure in Sweden, nor is it subject to any proportionality test. It is within the social partners' power to use the right in a responsible manner. The Laval judgment created distrust towards the EU. When the Social Pillar was proclaimed, the Swedish trade unions were positive towards the political initiative as long as it did not constitute a ground for adopting more EU legislation. ${ }^{75}$ The employers' associations were not as positive and feared the adoption of more EU legislation. This shows that EU law's characteristic of sometimes being a 'jack-in-the-box' has led the social partners to adopt a joint strategy to block EU initiatives in order to avoid a loss of control and influence over the Swedish labour market. ${ }^{76}$

Third, the Swedish model is an 'odd bird' compared with the models of labour market regulation seen in the majority of the other Member States. Even if the EU is expected to respect the Member States' national identity (Article 4.2 TEU), social security models and social partners' autonomy (Article 153.4 TFEU), the solutions at EU level still tend to be of the 'one-size-fits-all' type.

The 'one-size-fits-all' approach is sometimes, depending on a Member State's negotiating power or shared interest with larger Member States, complemented by alternative ways of implementing measures or a possibility to derogate that might have a negative impact on the overall aim of a certain legislative act. As the adoption of the Transparency Directive shows, the wishes

74 Mia Rönnmar, 'Autonomous Collective Bargaining in Sweden under Pressure' in Julia López López (ed), Collective Bargaining and Collective Action: Labour Agency and Governance in the 21st century (Hart Publishing 2019).

75 See statement from the Swedish Trade Union Confederation made 17 November 2017, www.lo.se/start/tal_och_artiklar/den_sociala_pelaren_ett_valbehovligt _komplement_i_eu accessed 17 Juñe 2021.

76 The concept is borrowed from Kaarlo Tuori, 'EC Law: An Independent Legal Order or a Postmodern Jack-in-the-Box' in Iain Cameron and Alessandro Simoni (eds), Dealing with Integration: Volume 2, Perspectives from Seminars on European Law 1996-1998 (Iustus 1998). 
of one or a few Member States can limit the intended aim for the rest. In other words, the autonomy of one Member State's trade unions may reduce the struggles of trade unions in other countries. In order to reconcile the interests in one Member State with the aim of strengthening the European social dimension in general, the EU might need a new constitutional framework that both promotes common aims and, to a larger extent, respects the national identity of each Member State. It could be a framework in which both the Member States' and the EU's positions are strengthened. Furthermore, it could be a reinforcement of the political over the juridical.

Fritz Scharpf has presented a fairly well worked out suggestion for a new constitutional framework. ${ }^{77}$ Even if he seems to have low expectations that his Proposal will become a reality, and even if it can be considered quite radical, ${ }^{78}$ it gives an inspiring account of what EU could be. His idea, in short, is that the EU project should have a more pluralistic view when it comes to democracy (demoi-cracy). This would entail fewer common solutions than are seen today. According to Scharpf, only traditional constitutional values, and not the present economic constitution, should be maintained. ${ }^{79}$ Such values could be taken from the Member States' constitutions and from Article 2 TEU. Furthermore, other institutions apart from the Commission should have the right to propose legislative acts. In order to facilitate the legislative procedure, he proposes that legislation be adopted by a majority decision in the Council and the European Parliament. At the same time, it should be possible for Member States to opt out of certain legislative acts. Such opt-outs could be motivated by national characteristics of constitutional value - for example, the Swedish model. The safeguarding of national identity should be able to trump the supremacy of EU law. ${ }^{80}$ To avoid opt-outs motivated by national measures that are contrary to traditional democratic values, it should be possible to reject an opt-out by a majority in the European Parliament and by a qualified majority in the Council. In the spirit of plurality, it should also be possible for a group of Member States to initiate a collaboration and adopt legal acts applicable only to that group of Member States. A strategy that contains the use of opt-outs and regional collaborations would probably benefit the Swedish model.

The main idea of Scharpf's Proposal is to strengthen the political process on both Member State and EU level. ${ }^{81}$ A pluralistic legislative procedure, together with a limitation of the constitutional character of the internal market,

\footnotetext{
Scharpf (n 30).

Garben (n 7) 331.

99 Scharpf (n 30) 400.

80 The question is if today's constitutional framework already provides that possibility: see $\mathrm{n} 21$.

81 Scharpf (n 30) 401.
} 
could give the Member States increased possibilities to use different solutions to reach common goals. In conclusion, a pluralistic approach to governance would benefit Member States with a minority interest. An EU that moves towards a more decentralised power provides a safeguard to national characteristics such as the Swedish model, while at the same time ensuring high social standards in the EU as a whole. 